Psychology. Journal of the Higher School of Economics.

2016. Vol. 13. N 3. P. 558-575.

\title{
PSYCHOLOGICAL STUDIES OF THOUGHT: THOUGHTS ABOUT A CONCEPT OF THOUGHT
}

\author{
V.D. SHADRIKOV ${ }^{a}$, S.S. KURGINYAN ${ }^{a}$, O.V. MARTYNOVA ${ }^{a, b}$
}

\author{
${ }^{a}$ National Research University Higher School of Economics, 20 Myasnitskaya Str., Moscow, 101000, \\ Russian Federation \\ ${ }^{b}$ Institute of Higher Nervous Activity and Neurophysiology of Russian Academy of Sciences, 5 A Butlerova \\ str., Moscow, 117485, Russian Federation
}

\begin{abstract}
The concept of thought has always been central to understanding the nature of human thinking in psychological studies. However, the main question of what is thought still remains unanswered. The origins of the issue lie in the definition of the original unit of analysis, i.e. in the definition of what lies at the heart of image, belief, imagination, speech, consciousness, and thinking. Based on available studies, results of which were reflected in recent publications it was argued that thought should be such an original unit of analysis. This article explores the concept of thought based on cognitive constructs and the neurophysiological correlates of mental activity. The present study is addressed to discuss issues dealing with the nature of thought, its content and structure, and the relationships between indicators of substantial thought and the neurobiological correlates of the process of thinking. Structurally thought is based on needs, emotions and intensions, and as such, thought defines the substantive essence of an image and also represents consciousness. Coherence of thoughts and consciousness, their integrity reflect the connectivity of things from the external world in their entirety. Thus, the ability to generate thoughts and build relationships within the stream of consciousness characterizes the human mind. It is shown that thought as a cognitive substance emerges from desires and experiences, as well as from conscious perception. Taken together, the described psychological and neurophysiological assumptions open up new horizons for research into human mental activity, thinking abilities and consciousness.
\end{abstract}

Keywords: cognitive neuroscience, motivation, thinking, thought, thought generation.

\section{Introduction}

Aristotle considered thought as essential to the understanding of human nature. Moreover, he argued that all the virtues of soul are related either to temperament or to thought (Aristotle, ca. $350 \mathrm{BCE} / 1930$ ). Over the next two millennia, the best minds of humankind have been turning their attention to the question of thought nature. A sufficiently complete analysis of this matter is contained in the study of Zinchenko (2012) who attempted to pull together facts concerning the experience of thinking about thinking. However, the problems of thought were gradually left behind by psychology.

The study was prepared within the framework of the Basic Research Program at the National Research University Higher School of Economics (HSE) in 2015. The article was also granted by Russian Academic Excellence Project '5-100'. 
Moreover, even the thinking process began to be viewed in isolation from the concept of thought.

Experimental and empirical data accumulated over the past half-century allows us to raise the question of the need to study human thought in various aspects, starting with its definition and structure. In support of the above we present an estimation of the dynamics of interests in psychology made by Rita L. Atkinson. She noted that over the past century the point that had been the focus of attention in psychology had made a full circle. After rejecting the experience of consciousness as the object of psychology because of being of little use for scientific analysis and turning to the study of external observable behaviors, psychology again returned to the construction of theories of hidden aspects of the mind, this time having better tools for scientific research (Atkinson, Smith, Bem, \& Nolen-Hoeksema, 2000). It is safe to say that the same applies to a thought as an object of psychological investigation. Forgotten along with the psychology of consciousness thought shall once again become one of the most important research subjects in psychology.

New non-invasive neurocognitive technologies give hope for discovery of the relationship between brain activity and consciousness. However, despite a certain progress in finding brain mechanisms of cognitive actions, the essence of thinking mechanisms remains a mystery. It seems to us that origins of the issue lie in defining the original unit of analysis, in defining what is the basis of an image, idea, word, consciousness, and thinking. In our view, human thought should serve as such an original unit of analysis.
In the present research we rely on three methodological principles of psychological studies introduced by Sergey L. Rubinstein (1973). The first principle is the principle of psychophysical unity which has two aspects to it. One aspect is that the connection between mind and its substrate can be explained as the relationship between structure and function, whereas the other aspect is that the connection of consciousness is defined as a reflection and as knowledge with the object reflected in it. The second principle is the principle of unity of consciousness and activity. According to that principle, thought is always functional by nature and reflects motivation of an individual (who is seen as a subject of an activity). Finally, the third principle (used as a basis for our investigation), is the principle of unity of knowledge and experience. It assumes studying the connection between thoughts and experiences.

At first, let us examine the process of thought generation from the standpoint of neuropsychological knowledge using the principle of psychophysical unity. This issue was of interest to Ivan M. Sechenov, who studied the physiological mechanism of thought generation at the level of physiological beliefs of his time. In particular, he stated that separateness of objects corresponds to separateness of physiological perception responses and their traces in the neural organization; comparing them with each other corresponds to continuity of propagation of neural processes in acts of perception, while links (directions of comparison) correspond to partial similarity between successive perception responses and their traces in memory (Sechenov, 1938). While per- 
ceiving the same object repeatedly in variable objective and subjective conditions of perception, an individual distinguishes some of the object's attributes and at the same time perceives it as a whole. Such simultaneous perception of an object and its attributes, as noted by Sechenov, is an actual substantive thought.

Contemporary neuropsychological studies allow us to turn to the examination of psychological functions and, in particular, processes of perception on the part of the brain processes which implement them. According to Karl Pribram, in the 1960s behavioral psychology appreciated the main idea of gestalt psychology that subjectively experienced consciousness is such an important part of the biological and conscious world that it shall not be ignored in the study of behavior (Pribram, 1971). Therefore, respectable psychologists proceeded to studying such processes as learning, thinking and attention. Pribram wrote that by the end of the sixties, the problems of image generation were discussed at meetings of psychologists openly and without risk. Two of the central issues of those studies were investigation of neuropsychological mechanisms of image creation and the problem of distinguishing image attributes. Studies conducted with microelectrodes showed the existence of neurons that responded only to a certain stimulus, i.e. a direction of movement, a slope of line, etc. According to Pribram, recognition of structures is a result of the extraction of attributes at the entry, which occurs due to individual neurons or small groups of neurons, and the perception of visual structures is carried out by a hierarchical system of such attribute detectors. Another characteristic feature of attributes extraction is the fact that it occurs with the participation of memory neurons, and that perception system itself is self-adaptive and being controlled by its own history (Ibid.). Based on his own studies and other scientific data Pribram concludes that it is wrong to view perceptual processes as an imageless analysis of attributes. Attributes are always associated with a certain image and such association with an image is a substantive thought. This system of relations between image and its attributes is the essence of learning process. In addition, since the relationship between attribute and image is implemented through thought, the essence of the learning process is determined by the relationships of thoughts. Also assumptions set forth by Vekker (1976) should be noted that procedural dynamics of mechanism and integral characteristics of the results in a psychological act are attributed to different subjects: one to an organ, and the other to an object.

Significant factual material that sheds light on the neuropsychological basis of thought generation and operation can be found in the research carried out by Natalia P. Bekhtereva (1978). In her studies the inseparable relationship between emotional and mental activity was shown that served as an experimental confirmation of our assumption about the unity of intellectual, motivational and emotional components in thought. On the basis of numerous findings of the structural and functional organization of human brain, Bekhtereva suggested that mental activity was ensured by ensembles of both cortical and deep brain structures. She highlighted that it was necessary to 
maintain a reasonable attitude towards the material basis of mental activity and to conduct a focused and increasingly deep search in its decoding. However to discover what is ideal we need to try to exceed the limits of materialism (Ibid.).

A similar opinion is expressed by Tatyana N. Ushakova in her research on the problem of relationship between speech and thought. She emphasizes that it is paradoxical that to this day given issue escapes from solution and remains rather mysterious (Ushakova, 2011). Giving an explanation of this situation, she points out that "its invincibility lies in the fact that it is necessary to trace the connection between the two seemingly disjoint areas of the human mind: the sphere of nonmaterial consisting of human consciousness, thoughts and feelings, on the one hand, and physical and material phenomena of sounding or recorded speech - on the other" (Ibid., p. 210).

One of the interesting approaches to solving the problem of consciousness is contained in the theory of information synthesis by Ivanitskii (1997), according to which conscious perception occurs because of circulation of impulses with activation of memory centers, including hippocampus, and circulation of motivational structures with the subsequent return of excitation to the projection cortex. This mechanism makes it possible to compare and synthesize information on the physical and signaling properties of a stimulus, which we believe is the basis of objective thought about perceived images.

Modern brain research techniques such as direct detection of firing activity of neurons and neural populations, study of EEG, positron emission tomography (PET), functional mag- netic resonance imaging (fMRI), steady pathological conditions, along with neurochemical methods, allowed to start a macro mapping of the brain for higher cognitive functions. For instance, various methods of fMRI signal processing make it possible to study visual perception from the sensory level to the higher associative level in the brain (Haxby, 2012). The other progressive line of research is devoted to speech perception mapping, including perception of individual speech sounds (Formisano, De Martino, Bonte, \& Goebel, 2008; Maiorova, Martynova, Fedina, \& Petrushevskii, 2013), as well as elements of the semantic analysis (Hagoort \& Levelt, 2009). In addition to visual and verbal images decoding, fMRI allows under certain experimental paradigms to determine neural networks of higher brain functions such as a decision-making process (Klucharev, Hytönen, Rijpkema, Smidts, \& Fernández, 2009) and the functional substrate of spatial and verbal thinking (Ivanitskii et al., 2013).

Although it is undeniable that thoughts have neural correlates, there is still a fundamental question of what the mapping of active brain regions really tells us about actual cognitive mechanisms and brain functioning in general. Even though definition of thought-specific structures and their interactions using brain mapping with noninvasive neuroimaging is an important tool, it is not sufficient for understanding of the process of thinking (especially since brain regions active at the time of different mental operations tend to overlap, while within more complex cognitive tasks more cortical regions can be active). This overlap of functions in different anatomical brain 
regions is a counterargument for the majority of localization theories, that sways modern scholars towards systemic and dynamic concepts of the most complex cognitive mechanisms, including the objective thinking as well. In the Russian neuroscience principles of functional systems were offered by Anokhin (2013) in order to explain the work of individual neurons and neural ensembles, as well as of higher mental functions. The systemic view of the brain functioning, similarly to Cartesianism, borrows mechanistic or rather cybernetic principles. For instance, the concept of reverse afferentation offered by Anokhin intersects with the cybernetic concept of feedback offered by Wiener (1965). At the end of the 20th century the introduction of mathematical concepts into the theory of mind, consciousness and thinking found a greater response in neurophysiological and psychological studies. For instance, an American physicist and engineer Arthur S. Iberall became the founder of homeokinetics theory, physics of complex systems (Soodak \& Iberall, 1978), the principles of which are also used to define mental activity, where dynamic thinking and general dynamic adaptive properties of neural system are explained by the physical concept of the system metastability. The meaning of metastability is based on the understanding of information-related self-organizing dynamic systems, such as brain and thinking. In coordination dynamics of metastability is the result of a broken symmetry of the system of combined (nonlinear) oscillations. According to dynamic functional organization certain parts of the brain tend to operate independently and at the same time tend to operate in coordination with each other (Kelso, 2008). A number of researchers acknowledge that metastable dynamics of the brain module networks may be the basis of mechanisms of different cognitive functions, including consciousness (Edelman, 2003; Freeman \& Holmes, 2005). How does the concept of the metastable dynamics help in understanding of mind? The contents of mind and the dynamics of thinking are inextricably linked. Thoughts are not static: as in the flow of a river they appear and disappear as patterns of a constantly changing dynamic system. The content of thoughts depends on activated neural structures. Thoughts arise from within, along with the activation of neural structures associated with memory and emotions, such as hippocampus and amygdala. Thoughts can be triggered from the outside by a familiar sound, touch, smell or visual object. A dynamic interplay of these structures occurs in accordance with the principles of metastability. However, much remains for understanding on what the content of consciousness is, which by nature depends on the context.

It seems to us that origins of the problem lie in the definition of the original unit of analysis, i.e. in the definition of what lies at the heart of image, belief, imagination, speech, consciousness, and thinking. Based on available studies, results of which were reflected in the recent publications (Shadrikov, 2013, 2014), we argue that thought shall be such an original unit of analysis.

\section{Thought as a substantive being}

Based on the above neurophysiological background for the process of 
thought generation and the basic principles of psychological studies, we will try to answer the question: "What is thought?" For this purpose we shall start with a brief analysis of the function of psyche as a whole, as well as what kind of place is given to thought in it.

It is generally accepted that the psyche has evolved to ensure survival of living organisms, and increasing complexity of environment caused its development. However, what does to ensure survival mean? It means to avoid danger to life and find what is needed for feeding the organism and continuing the genus and species. What does this require? It requires the psyche to be able to provide the survival-related information about the outside world and organize behavior in accordance with the available information on the current state of environment and experience. In general, this means that the psyche controls the individual's relationship with the outside world in order to build behavior maintaining his existence or his life. First of all, an individual must be an entity. Beyond this entity all problems of human existence are gone. To be means to exist in the world; human life can be defined as existence in the outside world, from birth to death, through active interaction with the outside world, the cause of which lies in the human nature (Shadrikov \& Cheremoshkina, 1990). The basis on the need of being is the most important methodological principle in the studying of human psyche.

Thus, the psyche always has a functional nature. A function of the psyche is to provide a person with information about environment and to build adaptive behavior.
We limit the following discussion only to the function of learning. What does it mean to learn? Firstly it means to be able to distinguish single objects (a thing as well as a phenomenon or occurrence) within environment, secondly to differentiate individual attributes of those objects, and thirdly to assign a meaning to those attributes to ensure survival and development. In the framework of psychological categories, differentiation of objects and their attributes is carried out within the processes of feeling and perception. Results of the process are images of objects and their attributes. Thus, the first function of psyche is to produce images and attributes of objects of the outside world. It is important to emphasize the unity of an object's image and its attributes. This is a key point because an image without attributes turns into a phantom. The unity of an object's image and its attributes is expressed in thoughts. As such, thought carries the link between image and its attributes.

Having examined the mechanism of integrating an object's image and thoughts about properties of that object we actually approached the problem of image interpretation. This means filling an image with thoughts and reflecting properties of the object represented in such an image. Image interpretation occurs within human behavior and activity, and has a functional nature, i.e. thought's properties detected in image (if any), which are important for actual behavior, are also important for problem solving within such behavior.

Examining the process of perception Myasischev (1960) noted its meaningfulness. In considering such meaning- 
fulness he highlighted that perception content was of subjective importance to a perceiver rather than the relationship of individual objective components of perception. Here subjective is seen as something that is introduced by the subject, but not present in the perceived object. This is a very important point. Thought is always subjective, unlike information.

\section{Defining thought content and structure}

Having observed thought through the relationship between an object and its attributes, we found only one aspect of thought. It is important to note that perception, as has been already mentioned, has a functional nature, and attributes of a perceived object always have functional nature as well, i.e. they are directly related to an activity or act performed by the perceiver. Consequently, an object attribute is endowed with a certain meaning determined by the essence of performed activities. Thus, we can say that thought not only reflects relationship between an object and its attributes, but it is also endowed with a certain content, expressed in terms of the meaning of a perceived attribute. In other words, relationship between an attribute and image is ensured by thought which carries a certain functional content. In this case we are dealing with implementation of the psychophysical principle as interpreted by Rubinstein (1973). On the one hand, thought reflects the relationship between a neuropsychological substrate and psychological function, and on the other hand, the content of thought reflects its relationship with the perceived object.
Herewith the image content has functional nature, which shows the principle of unity of consciousness and activity in action.

Based on the points made we could examine the substantial characteristic of thought.

It has been noted that thought reflects the objective content. Every thought captures only one side of an object. Moreover, initially image is associated with thoughts related to the outer side of the object. Further, the content of these thoughts (external attributes) is disclosed. A person seeks to establish their meaning and subjective significance. This disclosure of the meaning of thoughts is the essence of the process of intellectualization. This process occurs within the human life activity. Image and its attributes expressed by thoughts (what may be called thought-attributes) become included into life where their semantics is established. Thus each "thoughtattribute" gains a particular individually meaningful content (meaning) and therefore thought becomes enriched. Here it should be said that any thought-attribute included in various situations or various forms of life activities will be endowed with new content.

Thought is always subjective since it is produced by a "thinking individual". As such we are dealing with the process of thought subjectivation that, as already mentioned, has three stages. The first stage is the thinking individual's need objectivation within a thought. The second stage is the thought "wrapping" in moral statutes of the individual. The third stage is sociocultural subjectivation of thoughts. To the extent to which an individual is raised in a particular cul- 
ture, they will perceive the external world in the context of such culture. For example, for someone the poppy is a flower and a plant with apotropaic properties, while for a Russian peasant it used to be an object which had some magic power and protected from evil. For a contemporary of ours the marten is an animal with valuable fur, while within folk culture it is an animal with female, marital, erotic and weaving symbolism. A doll may be seen as an attribute of children's games, while in folk beliefs it is an object for rituals and magic acts. The word "circle" in the modern sense means a mathematical figure, while in the traditional sense it is the most important mythological symbol that reflects the cyclical nature of time, division into "us and them", motion in circle has a special symbolic meaning. Details of different ethnolinguistic meanings of various concepts of Slavic culture can be found in the ethnolinguistic vocabulary (Tolstoy, 2005-2011).

People who have grown up in different cultures will endow the same objects with different (non-matching) meanings, and their thoughts arising therewith will be different. On this occasion, Spengler (1991) wrote that we were hardly even able to imagine how many great thoughts from other cultures found in us their destruction, because based on our thinking and its borders, we either were not able to assimilate them or believed that they were false, useless, and meaningless. Therefore, filling an image with thoughts will depend on socio-cultural factors.

Another factor that we have already touched upon is the dependence of thought on the moral statutes of an individual. Above we quoted Aristotle's opinion that all the virtues of the soul are related either to temperament or to thought. Now we need to go further. Thought itself depends on human morality. Here we are dealing with conjunction rather than with disjunction. Bergson (1935) subtly noted that in human prehistory mind and morality existed in unity as a whole. Mind and morality are contained within each other. Moreover, when looking back into history, we can find morality closer to mind and mind closer to morality than in the modern world. The mind used to design moral requirements. Morality led societies and individual behaviors within societies. However, even nowadays mind is enmeshed and controlled by morality, and in morality we can see activities of mind. Morale directs perception and determines not only the perceived image of things (objects, phenomena, events), but also the content of these images and thoughts associated with them. Influence of morality requirements on thoughts and images can also be classified to the process of image intellectualization. It must be noted that usually image is understood as an image of a thing, but we have not made a mistake when we attribute image to phenomena and events. If we define image as a specific system of thoughts related therewith, then phenomena and events will also have their images.

Bernstein (1967) showed (perhaps with very few exceptions) that no movement could be coordinated by the leading level of movement scheme alone. At the beginning of shaping a new motor skill all corrections of movement are made by the "initiator level". The situation changes as each technical 
aspect and detail of performed complex movements sooner or later find a specific level among the lower levels whose afferentations are most relevant to the given movement according to the provided sensory corrections. Therefore, a multilevel motor scheme develops gradually as a result of successive switches and leaps. The movement scheme is controlled by the leading level which is most relevant to the semantic structure of the motor act and which provides only the most basic, semantically decisive motor corrections. We assume that Bernstein's leading level of corrections and separate parameters of motor acts are reflected in certain thoughts. In general, movement (action) is perceived as an image of movement, while action alone is perceived as an image of a motor action filled with individual thoughts on the parameters of movement.

Finally, the process of thought intellectualization determined by the needs of a thinking individual should be examined. As shown by studies carried out in the school of Konstantin V. Sudakov, relevant needs related to a vital constant generate a motivational state that determines an active attitude towards stimuli of the outside world, triggers past experience and thereby contributes to a focused organization of behavior. It is shown that chemical selectivity of cortical mechanisms arises from dominant motivation, and selection of the outside world stimuli which are capable of meeting the relevant need takes place (Sudakov, 1993). It is important to note that motivational state associated with a relevant need is accompanied by emotions. Consequently, an objectified need in the form of qualities of items from the external world is also followed by emotions. Therefore, thought that reflects the connection of need with qualities of items from the external world, which are capable of meeting the relevant need, is accompanied by experience.

Although we have used the terms "emotion" and "experience", at the level of neuropsychological mechanisms of behavior organization we speak about a neural substrate regulating the goaloriented behavior and use the language of biological terms. On the psychological level of the problem analysis, we speak about desire, will, thought, image and experience. The neural substrate of emotions in this case acts as a system of biological detectors that transforms a signal about the need into a sensation (feeling) of pleasure-displeasure, under the influence of which the biological need is experienced as a psychological fact. Experience can be realized and not realized. There is a threshold of the experience awareness. Therefore, taking into account the functional nature of mind, thought as a reflection of certain qualities of an object, which can satisfy the relevant need, is accompanied by experience.

As a summary of the above stated it is possible to propose the structure of thought. It consists of three components: content, need and experience. The unity of these three components represents thought as a living knowledge. Because of the connection with needs and experiences thought is different from information which is characterized only by its content. We believe that unique characteristics of thought and, consequently, of image lie within such structure and are manifested in the fact that people think with thoughts. Thought is a substance based 
on needs, emotions and intentions (conceptions formed by directing mind towards an object). As such, it enters an individual's inner world. In this form it is stored in the human memory: connected with objects of the external world and their qualities as well as human needs and experiences.

Having defined the thought's content and structure we have to introduce a further point for consideration. That is the relationship between thought and information.

A founder of cybernetics, Norbert Wiener, defined information as one's own content of themselves and their feelings obtained from the outside world in the process of adapting to it (Wiener, 1965). In this definition Wiener emphasizes that information is the content which deals with properties of objects from the external world and that information exists independently from the person who obtains it through mental processes. At the same time in this definition we see that there is a connection between information and a learning subject, although the line of reasoning on its conditionality by motives and feelings related to learning is not developed. In most studies of the use of information in technical devices this relationship is completely lost. Content as information characteristic of an object becomes dominant. In this case, the subject (person) deals with information models of the outside world. Content in these models is represented at the level of meanings, allowing different users, firstly human beings, to understand the information. Most frequently we use words "concept" and "conception" to express meanings. These words represent a specific code for transmitting information from one human being (source) to another (recipient).

Thought not only contains information but also carries motivational and emotional components. A person generates a thought which becomes a part of the person's existence, and because of that this thought has a definite meaning to the person. For a particular person the outside world is represented in the content of consciousness, above all, in the form of a semantic model that reflects the content with its relevance to a particular human life. These semantic models form the content of an individual mind and its perceived part that is consciousness. In consciousness the outside world is represented by external information and semantic models that overlap but are not identical. Thus, an appeal to thought as an initial construct allows us to understand the relationships between thought and information, information models and semantic models.

\section{Thought generation}

Having examined the nature of thought and its representation within the human psyche we shall address an issue of how thought is generated. To answer this question, we should rely upon the methodological principle formulated above on the role of the psyche in ensuring human existence.

Traditionally, researchers look for an answer to the above mentioned issue in a cognitive sphere. It can be explained by the fact that they proceed from the concept of "information" and its role in the organization of behavior and activity. Relying on our understanding of thought as a need-emotionintentional substance we would like to 
state a hypothesis that thought emerges from desires and experiences. Desire directs search for an object and/or an action that can meet the relevant motive. As such desire creates a thought about the object that can meet the relevant need. Desire directs the search and is shaped in the process of objectification into thought, and the thought begins to act in unity with motivation and content related to the object that can meet the need. So desire can be related not only to an object, but also to an action, in that case there is a thought for a specific action. Transition from desire to thought has three stages. In the beginning the motive (need) appears as a wanting that can be realized or not realized (first stage), then wanting under certain conditions transforms into desire that is objectified and expressed in a thought about the object of desire (second stage), and finally the thought about the desirable object is implemented through a thought about an action. This is a process of thought generation that involves thinking. It works with the content of psyche, which reflects the substance of thought about objects that can satisfy the need, required actions and conditions of life activities. Thinking implements the decisionmaking function or choices such as what object and in what way can meet the relevant motive (discharge the motivational state). This can be exemplified in the situation that deals with student.

Let us say you are a student. A second or third lesson of the day is over. You start feeling hungry. You understand that you want to eat. Passing by the cafeteria, you walk in and depending on what is on the counter and how much money you have, you decide to purchase a specific product (a salad, a patty, etc.) At this stage, your wanting transforms into a specific desire that is implemented in the act of purchase. Most purchases are made according to this scheme, and successful advertising works by translating your motive to be attractive into wanting to buy, and then into a desire to purchase a particular item. However, let us see how the above scheme looks from the side of the process of thought generation. Awareness of hunger produces the thought that it is time to eat something. This, in turn, produces the thought of how to do it. Perhaps you have a sandwich that you brought from home. If you have nothing, a thought is produced that it is necessary to go to a cafeteria; the perception of products in the cafeteria produces a thought of what you would like to eat. A desire of a particular item produces a thought of its cost and a thought of your financial capabilities. Next a thought of what you will buy is produced, which is then translated into a thought of what you should do. The process is completed with purchasing of an item that will be consumed by you as food. The process can continue, if you do not find that you have eaten enough or have doubts whether you have bought the right item, etc.

In this example it is important to emphasize that thought is produced out of desire. It deploys the thinking process associated with an assessment of factors that ensure satisfaction of desire. It should be pointed out that a motive (need) is reflected in every thought which leads to the production of such a thought. Every thought is accompanied by certain experiences related to the motivation which created 
such a thought. The described process of thought generation superimposes processes of biological motivation (Sudakov, 1993) and through them acquires its ontological essence. The mechanism of behavior motivation conceals the process of producing the objective (substantial) thought. The central point of this mechanism is establishing the properties of an object from the external world which ensure meeting the needs and maintaining the existence of an individual. At the same time, object properties are associated with object and motivation. A link between property and object, as shown earlier, is expressed by thought which is associated with motivation producing such a thought in the first place. This is how the outside world is learned and transformed within the inner world into a semantic model.

On the psychological level, the process of thought generation in meeting relevant motivations includes past experiences, knowledge of thought attributes describing the individual objects and their subjective significance, conditions of satisfaction of the relevant motivation and consequences of such satisfaction. In short, every step of thought generation is described by a deployed decision-making process in which the thought plays a leading role. The content of the psyche associated with satisfaction of a motive within thinking processes leads to specific solutions reflected in respective thoughts. A set of thoughts related to meeting relevant motivation is integrated into a mental semantic model associated with a particular life activity. Such a model can switch from the current state into a potential state and can be actualized again when a similar situation occurs. These transitions shape patterns of behavior and activity. Thus, understanding of the process of thought generation from needs and experiences can only be possible if thought is presented as a substance based on needs, emotions and intentions.

Let us consider another example that deals with feelings as a key point in understanding of the process of thought generation. An excellent example is given by a Roman philosopher Lucius Annaeus Seneca in his work "Moral letters to Lucilius" (Seneca, 2011). The author argues on who can consider themselves lucky. Here it should be noted that "consider themselves" can be understood here as "think of themselves as." Addressing to Epicurus Seneca says one who does not consider himself as the most blissful is unhappy even if he rules the world. Then he refutes his own statement in his dialogue with Lucilius by asking what would you say if one who has made a fortune dishonestly declares oneself blissful and can one become blissful upon one's own declaration?" For Seneca this is a rhetorical question because it doesn't matter what he thinks, as only what he feels is important and not something that he's feeling today but what he always feels (Ibid.). So, a person may think of himself as happy if he always feels happy. Therefore, a feeling is the basis of thought. In addition, this feeling mainly refers to moral well-being. In this respect, we can refer to the indicative argument of Henri Bergson about the relationship between emotion and feeling. He stated that there are emotions that create thought, for example, even invention (although it is an intellectual phenomenon) may have 
emotional components. In keeping with this argumentation we see that emotion with respect to subsequent mental states is a cause and not a consequence. Emotion can create new ideas. It is super-intellectual (Bergson, 1935).

The premise is that the process of thought generation is determined by consciousness should be addressed to consideration. The content of consciousness is currently realized as a part of an individual mind. Here "current" means important at this time of life of a particular individual, passing from a potential content of mind into an active form. While studying the content of consciousness in psychology, we always deal with personal consciousness. By its nature, any thought is produced by the subject of life activities, therefore, every thought carries with it not only qualities of an object from the external world, but also qualities of its generator. Therefore, every thought is personal. In their unity and substantial integrity thoughts form part of the content of personal consciousness. Thoughts of different individuals in relation to the same object are not identical (we do not undertake now to discuss the question of the significance of these differences). On this occasion, even James (1892) stated that the worst that psychology could do was to begin to interpret the nature of personal consciousness, depriving it of individual value. In this case, under the personal consciousness James considers "related sequences of thoughts, created as such" (Ibid., p. 114).

Coherence of thoughts and consciousness, their integrity reflect the connectivity of things from the external world in their entirety. This con- nectedness is our understanding of the outside world, since individual thoughts when produced have a functional nature. Violation of this integrity is the problem of misunderstanding, which is one of the central problems in educational psychology. It comes from the fact that the content of textbooks reflects thoughts of the authors, and we have noted that personal contents of consciousness are not identical. When we speak about producing a thought related to an object, we note that such a thought is related to the personal consciousness, to the subject who produces such a thought. However, this is only one side. The other is related to the situation in which there exists an object which is associated with thought. In light of this, we understand why our view on the same object changes in different periods of our lives and in different situations. Human consciousness constantly interprets subject environment (generates new thoughts). Ability to generate thoughts and build relationships within the stream of consciousness characterizes the human mind, or intelligence.

\section{Conclusion}

Theoretical searches based on interdisciplinary data allow us to make certain judgments about what is thought and how thought is generated. We assume that thought is created from needs and feelings. Moreover, to the same extent to which our needs and feelings cannot be recognized, we cannot recognize thoughts produced by such needs and feelings. Thus, since we are aware of only a small portion of our needs and feelings, we are not aware of a significant part of our thoughts. The 
ontological essence of thought lies in the mechanism of thought generation from feelings and needs. Only at the level of awareness of "what I want and what I wish", thoughts can be generated about "what I want and what I wish", and this stage involves substantive thought on "what I want and what I wish". In order to realize the fact of wanting there is a threshold of needs and experiences. Virtually everyone has experienced the state of vague wanting or feelings. It is shaped by unconscious thoughts about wanting. This desire or experience may not be objectified. In the beginning thought focuses on the need or feeling, and only at the stage of implementation of such a need there comes a thought about an action or about an object for meeting the need or about a task related to a specific purpose. In terms of the metastable dynamic system of neural networks, neural mechanisms of the thought process tend to be a particular attractor (a possible object of thought), but if there is another strong enough factor, the dynamic system of brain switches to such another attractor. This mechanism explains the phenomenon of thoughts leaping, as well as the fact that many mental processes are unconscious. Taking together, the described psychological and neurophysiological assumptions open up new horizons for research into human mental activity, thinking abilities and consciousness.

\section{References}

Anokhin, P. K. (2013). International Series of Monographs in Cerebrovisceral and Behavioral Physiology and Conditioned Reflexes: Vol.3. Biology and neurophysiology of the conditioned reflex and its role in adaptive behavior. Elsevier Science.

Aristotle. (1930). De anima [On the soul] (J. A. Smith, Trans.). In W. D. Ross (Ed.), The works of Aristotle (Vol. 3). Oxford: Clarendon Press. Retrieved from http://psychclassics.yorku.ca/ Aristotle/De-anima/index.htm

Atkinson, R. L., Smith, E. E., Bem, D. J., \& Nolen-Hoeksema, S. (2000). Hilgard's introduction to psychology (13th ed.). Orlando, FL: Harcourt College Publishers.

Bekhtereva, N. P. (1978). The neurophysiological aspects of human mental activity (2nd ed.). New York: Oxford University Press.

Bergson, H. (1935). The two sources of morality and religion. New York: Henry Holt and Company.

Bernstein, N. A. (1967). The co-ordination and regulation of movements. Oxford: Pergamon Press.

Edelman, G. M. (2003). Naturalizing consciousness: A theoretical framework. Proceedings of the National Academy of Science, 100(9), 520-524. doi:10.1073/pnas.0931349100

Formisano, E., De Martino, F., Bonte, M., \& Goebel, R. (2008). "Who" is saying "what"? Brain-based decoding of human voice and speech. Science, 322(5903), 970-973. doi:10.1126/science.1164318

Freeman, W. J., \& Holmes, M. D. (2005). Metastability, instability, and state transition in neocortex. Neural Networks, 18, 497-504.

Hagoort, P., \& Levelt, W. J. (2009). Neuroscience. The speaking brain. Science, 326(5951), 372-373. doi:10.1126/science.1181675

Haxby, J. V. (2012). Multivariate pattern analysis of fMRI: the early beginnings, NeuroImage, 62(2), 852-855. doi:10.1016/j.neuroimage.2012.03.016 
Ivanitskii, A. M. (1997). Sintez informacii v kljuchevyh otdelah kory kak osnova sub'ektivnyh perezhivanij [Informational synthesis in crucial cortical area as the brain base of the subjective experience]. Zhurnal Vysshei Neronoi Deyatelnosti Imeni I.P. Pavlova, 47(2), 209-225.

Ivanitskii, A. M. Portnova, G. V., Martynova, O. V., Maiorova L. A., Fedina, O. N., \& Petrushevskii, A. G. (2013). Kartirovanie mozga pri verbal'nom i prostranstvennom myshlenii [Brain mapping in verbal and spatial thinking]. Zhurnal Vysshei Neronoi Deiatelnosti Imeni I.P. Pavlova, 63(6), 677686.

James, W. (1892). Psychology: Brief course. New York: Harper.

Kelso, J. A. S. (2008). An essay on understanding the mind. Ecological Psychology, 20(2), 180-208. doi:10.1080/10407410801949297

Klucharev, V., Hytönen, K., Rijpkema, M., Smidts, A., \& Fernández, G. (2009). Reinforcement learning signal predicts social conformity. Neuron, 61(1), 140-151. doi:10.1016/j.neuron.2008.11.027

Maiorova, L. A., Martynova, O. V., Fedina, O.N., \& Petrushevskii, A.G. (2013). FMRI-study of speech perception impairment in post-stroke patients with sensory aphasia. Zhurnal Vysshei Neronoi Deiatelnosti Imeni I.P. Pavlova, 63(3), 328-337.

Myasischev, V. N. (1960). Lichnost i nervozy [Personality and neurosis]. Leningrad: Izdatel'stvo Leningradskogo Universiteta.

Pribram, K. H. (1971). Languages of the brain: Experimental paradoxes and principles in neuropsychology. Englewood Cliffs, NJ: Prentice-Hall.

Rubinstein, S. L. (1973). Osnovy obshhej psihologii [Issues of general psychology]. Moscow: Pedagogica.

Sechenov, I. M. (1938). Biographical sketch and essays. North Stradford, NH: Ayer Co Pub.

Seneca, L. A. (2011). Moral letters to Lucilius - Letters from a stoic (R.M. Gummere, Trans., Kindle ed.). Michael Hussey Publisher.

Shadrikov, V. D. (2013). Psihologija dejatel'nosti cheloveka [Psychology of human activity]. Moscow: Institute of Psychology of Russian Academy of Sciences.

Shadrikov, V. D. (2014). Thought as an object for psychological study. Psikhologicheskii Zhurnal, 4, $130-137$.

Shadrikov, V. D., \& Cheremoshkina, L. V. (1990). Mnemicheskie sposobnosti: razvitie i diagnostika [Mnemonic abilities: development and diagnostics]. Moscow: Pedagogy.

Soodak, H., \& Iberall, A. (1978). Homeokinetics: a physical science for complex systems. Science, 201(4356), 579-582.

Spengler, O. (1991). The decline of the West. New York: Oxford University Press.

Sudakov, K. V. (1993). Brain neuronal mechanisms of motivation and reinforcement: system organization of behavior. Journal of Integrative Physiology and Behavioral Science, 28(4), 396-407.

Tolstoy, N. I. (Ed.). (2005-2011). Slavjanskie drevnosti [Slavic antiquities]. Moscow: Publishing House "International Relations".

Ushakova, T. N. (2011). Rozhdenie slova: Problemy psihologii rechi i psiholingvistiki [The birth of a word. Problems of speech psychology and psycholinguistics]. Moscow: Institute of Psychology of Russian Academy of Sciences.

Vekker, L. M. (1976). Psihicheskie processy: Myshlenie i intellekt [Mental process: Thinking and intellect] (Vol. 3). Leningrad: Izdatel'stvo Leningradskogo Universiteta.

Wiener, N. (1965). Cybernetics or Control and communication in the animal and the machine (2nd ed.). Cambridge, MA: The MIT Press. 
Zinchenko, V. P. (2012). An experience of thinking about thinking. In F. E. Vasilyuk, V. P. Zinchenko, B. G. Meshcheryakov, V. A. Petrovsky, B. I. Pruzhinin, \& T. G. Shchedrin (Eds.), Metodologija psihologii: problemy i perspektivy [Methodology of psychology: issues and prospects] (pp. 207-230). Moscow/Saint Petersburg: Centr Gumanitarnyh Iniciativ.
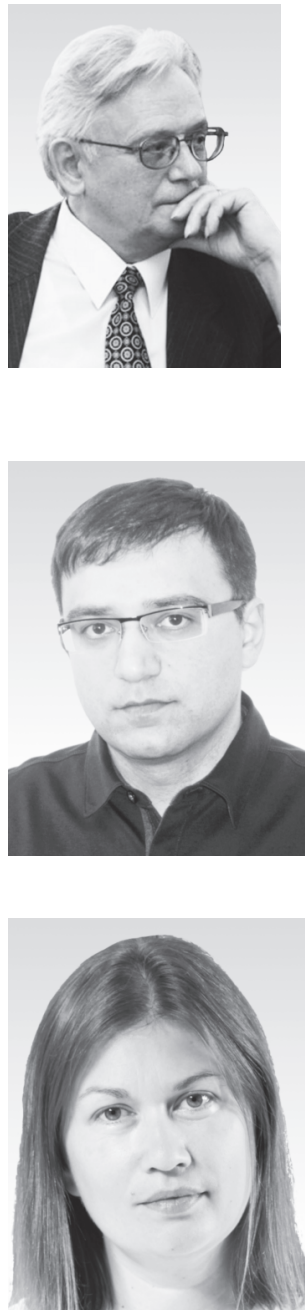

Vladimir D. Shadrikov - professor, academic supervisor, Faculty of Social Sciences, School of Psychology, National Research University Higher School of Economics, D.Sc.

Research area: mental development, human abilities, intellectual operations, structural organization of human thought, process of thought generation.

E-mail: shadrikov@hse.ru

Sergey S. Kurginyan - associate professor, Faculty of Social Sciences, School of Psychology, laboratory head, Faculty of Social Sciences, School of Psychology, The Scientific-Educational Laboratory of Ability Psychology, National Research University Higher School of Economics, Ph.D.

Research area: compensatory and adaptive mechanisms, mental resources, self-relation.

E-mail: skurginyan@hse.ru

Olga V. Martynova - head, Human higher nervous activity laboratory, Institute of Higher Nervous Activity and Neurophysiology Russian Academy of Sciences; senior research fellow, Centre for Cognition \& Decision Making, National Research University Higher School of Economics, Ph.D.

Research area: cognitive neuroscience, consciousness and neuroimaging of cognitive functions.

E-mail: olmart@mail.ru, omartynova@hse.ru 


\title{
Психологическое изучение мысли: Размышления о концепте «мысль»
}

\author{
В.Д. Шадриков ${ }^{\mathrm{a}}$, С.С. Кургинян ${ }^{\mathrm{a}}$, О.В. Мартынова ${ }^{\mathrm{a}, \mathrm{b}}$
}

${ }^{a}$ Национальный исследовательский университет «Высшая школа экономики», 101000, Россия, Москва, ул. Мясницкая, д. 20

${ }^{b}$ Институт высшей нервной деятельности и нейрофизиологии РАН, 117485, Россия, Москва, ул. Бутлерова, б. 5 A

\section{Резюме}

Мысль как один из конструктов психологического исследования всегда являлась ключевым понятием при изучении мышления человека. Тем не менее вопрос о том, что такое мысль человека, не являлся предметом исследования. Истоки этой проблемы коренятся в понимании «единицы анализа», т.е. того, что же составляет единицу анализа образа, убеждения, воображения, речи, сознания и мышления в целом. Опираясь на имеющиеся исследования, результаты которых обсуждаются в современных публикациях, высказывается и обосновывается утверждение, что единицей такого анализа должна выступать мысль. В настоящей статье рассматривается понимание мысли с опорой на когнитивные конструкты и нейрофизиологические корреляты ментальной активности человека. Данное исследование обращено к обсуждению вопросов, относящихся к сущности мысли, ее содержания и структуры, связи свойств предметной мысли с нейробиологическими коррелятами процесса мышления, мыслительной деятельности. Структурно мысль представлена как потребностно-эмоционально-содержательная субстанция, определяющая предметную сущность образа вещи (предмета), отраженного в сознании. Единство мыслей и сознания, их целостность представлены в связи вещей с внешним миром. Отсюда способность человека продуцировать мысли и устанавливать связи в потоке сознания будет характеризовать его ум. В настоящем исследование было показано, что мысль, как когнитивная субстанция, возникает из потребностей и переживаний, так же как и осмысленного восприятия. Рассмотренные психологические и нейрофизиологические предпосылки открывают новые перспективы для исследования ментальной активности человека, его мыслительных способностей и сознания в целом.

Ключевые слова: когнитивная нейронаука, мотивация, мышление, мысль, порождение мысли.

Исследование подготовлено в рамках программы фундаментальных исследований Национального исследовательского университета "Высшая школа экономики" (НИУ ВШЭ) в 2015 году. Статья представлена по проекту Russian Academic Excellence Project ‘5-100’. 
Шадриков Владимир Дмитриевич - профессор, научный руководитель, факультет социальных наук, департамент психологии, научно-учебная лаборатория психологии способностей, Национальный исследовательский университет «Высшая школа экономики», академик РАО, доктор психологических наук.

Сфера научных интересов: психология деятельности, способностей и ментальных качеств человека, индивидуализация способностей человека, эволюция мысли (культурно-исторический аспект, онтология мысли, мысль и познание).

Контакты: shadrikov@hse.ru

Кургинян Сергей Сергеевич - заведующий лабораторией, факультет социальных наук, департамент психологии, научно-учебная лаборатория психологии способностей, Национальный исследовательский университет «Высшая школа экономики», кандидат психологических наук, MA in Human Relations, доцент.

Сфера научных интересов: компенсаторно-адаптивные механизмы, психические ресурсы, отношение личности к себе.

Контакты: skurginyan@hse.ru

Мартынова Ольга Владимировна - заведующий лабораторией, лаборатория высшей нервной деятельности человека, Институт высшей нервной деятельности и нейрофизиологии Российской академии наук; старший научный сотрудник, Центр нейроэкономики и когнитивных исследований, Национальный исследовательский университет «Высшая школа экономики», Ph.D.

Сфера научных интересов: мышление, сознание, речь.

Контакты: omartynova@hse.ru 